\title{
'SPRINGS OF NEWNESS AND BEAUTY'? GRACE JANTZEN AND THE SEARCH FOR GOD ${ }^{2}$
}

\author{
Janet Trisk \\ College of the Transfiguration \\ Grahamstown
}

\begin{abstract}
One of the key foci in the work of Grace Jantzen is an investigation of how we speak about God and who does the speaking. In this article I describe two ideas she investigates, namely God as embodied and God as the divine horizon. A sub-theme is Jantzen's critique of the Western preoccupation with mortality, death and violence and her suggestion that we instead look for signs and metaphors of flourishing, 'springs of newness and beauty'.
\end{abstract}

Key Words: Grace Jantzen, God

\section{Grace Jantzen and her Works}

I had never heard of Grace Jantzen until, one chilly December morning, nearly ten years ago, I was wandering through Dillons Bookshop in Cambridge and, in the way that books sometimes do, one jumped out at me. The book was Becoming Divine: Towards a Feminist Philosophy of Religion. Because of a punishing exchange rate it was lunch or the book and the book won. But so too did I. I devoured it. I found, to my delight, the work of a feminist theologian which was to me both philosophically satisfying and written in a fresh, clear voice. Over the next few years this book proved again and again to be a point of reference in my own thinking until, uncharacteristically for me, I wrote to Grace Jantzen, and received a warm and encouraging response, apparently typical of the way she always sought to encourage her students and other new theologians. ${ }^{3}$ When she died last year, shortly before this colloquium was conceived, it seemed a good opportunity to honour her work by trying to present some of her thinking. So much for my story. Let me move now to hers.

Grace Jantzen was born in Saskatchewan, Canada. After studies at the University of Saskatchewan, she completed double doctorates in philosophy and theology; first at Calgary, and then at Oxford. Her last teaching position was at the University of Manchester. She moved not only from Canada to Britain, but from her Mennonite background to the Religious Society of Friends.

Grace Jantzen wrote six books in her curtailed life. ${ }^{4}$ (She was only 57 when she died from cancer in May 2006). They all display her interest in how we understand and speak about God. However, her primary task is not so much to tell the story of God as to explore who tells the story. Her writing displays an increasing awareness of how our concepts of God have been shaped by people with power. Her first work, God's World, God's Body

Thanks to my colleague Dr Jonathan May for his comments and suggestions on an earlier draft of this paper. See for example the obituary by Jeremy Carette in The Guardian, Thursday 11 May 2006: "Many students will know her seminar model of building ideas together rather than competing and destroying positions." She also completed a book started by a doctoral student, Hanneke Canters, who also died of cancer. 
(1984) is a philosophical essay in which she explores a way in which God may be holistically, rather than dualistically conceived. I shall say more of this later. This book led her to explore how the mystics, and especially Julian of Norwich, spoke of God and their union with God. Through her investigation of the writings of medieval mystics she became increasingly aware of the relationship between power and gender and what counted as knowledge (of God). This awareness was heightened by a four-year term (1989-1993) Jantzen spent working on the Canadian Royal Commission on New Reproductive Technologies. Here she became more deeply conscious of the relationship between power and knowledge, and, in her own words:

I began to take serious notice of who are the beneficiaries and who are the victims of power/knowledge... The glaring interconnection between power and gender which had been forced on to my attention in the study of new reproductive technologies and health care markedly shifted my focus in thinking about mysticism as well. In Christendom, after all, there was an overt link between the knowledge of God gained through the mystical life and the authority which could be claimed on the basis of that special knowledge (Jantzen 1995: xv).

This increasing awareness of the power/ knowledge matrix undergirds her last three books - Power, Gender and Christian Mysticism (1995), Becoming Divine: Towards a Feminist Philosophy of Religion, 1998 and Foundations of Violence, 2004.

Because they are the most explicitly theological of her works and because time and space do not allow for a full investigation of the full body of her fascinating work, my focus will be predominantly on God's World, God's Body and Becoming Divine. In both, though in very different ways, she explores ways of speaking about God and the other side of that coin, namely ways of understanding what it means to be human. In God's World, God's Body she also outlines, very briefly, her understanding of the doctrine of creation and in Becoming Divine she offers a fascinating alternative to the traditional Christian story of soteriology, which I will explore in some detail.

Before exploring her concept of God it may be helpful to consider briefly what turned out to be her last book, Foundations of Violence. The book was supposed to have been the first in a six-volume project entitled Death and the Displacement of Beauty in which she sought to investigate the roots of the preoccupation of the West with death and violence and to explore what might happen if we chose a new imaginary of beauty instead (Jantzen 2004:vii). In the preface to this work she sets out her hope for the project at the same time revealing her desire that readers will respond to her so that, in her words:

...we do not turn our eyes away from either beauty or violence; that we begin to hear

what each says to the other; that there may be healing and hope (Jantzen 2004: viii).

This last work, in some ways, helps us to understand much that has gone before in Jantzen's writing, and particularly her last three books, in which she challenges the dominant patriarchal story of God in which violence and death rather than beauty and flourishing are the concern of philosophers and theologians. Starting with Power, Gender and Christian Mysticism and developed in Becoming Divine and Foundations of Violence she seeks to open our eyes to what has counted as the right story and who has told it:

I suggest that much of traditional philosophy of religion ... is preoccupied with violence, sacrifice and death, and built upon mortality not only as a human fact but as a fundamental philosophical category. But what if we were to begin with birth, and with the hope and possibility and wonder implicit in it? How if we were to treat natality and the emergence of this life and this world with the same philosophical seriousness and respect which had traditionally been paid to mortality and the striving for other worlds? (1998:2). 
Jantzen's other story, the story of natality and beauty is the story which I will try to describe in this contribution.

\section{Who now is your God?}

Jantzen sets out in her first book, God's World, God's Body, to challenge the dualist assumptions of Western theological thought that separate God from God's creation, spirit from matter and soul from body. She instead proposes that we should view God as embodied. In order to develop this thesis she uses as her model our human experience of ourselves as embodied. We are co-extensive with, but not reducible to, our bodies. We transcend them in our openness to reason, to value and meaning, and in our emotions (Jantzen 1984:125). By analogy, she argues, God is co-extensive with the universe, but not reduced to it.

If God is personal and human persons are our best available model for an understanding of what God is like, then reconsidering the relationship between personhood and embodiment in human persons may help us to understand how God could be embodied in the universe (1984:124).

She is well aware of the dangers inherent in drawing the analogy of God to the human person, but argues (with support from the Christian tradition) that this is the best model we have (1984:12-20).

Through an investigation of the roots of dualism (in Platonic and early Christian thought) she illustrates how an incorporeal concept of God (which is derived from a dualistic understanding of humanity) came to dominate Western Christian thought. However, what she also illustrates is that this incorporeal notion of God, which was supposed to safeguard the ideas of limitlessness, omnipotence, omniscience, omnipresence, changelessness, indestructibility, transcendence and supremacy as creator of the world, was constructed in a particular thought world and is not necessarily the only way to conceive God (1984:35). She argues that it is possible to hold to these attributes of God and understand the universe as God's body. 5

Reconsidering what we might mean by God's unlimitedness, infiniteness and perfection she suggests that these attributes of God can be fully consistent with an understanding of God's corporeality - the universe. Furthermore, it is both philosophically and religiously advantageous to see the universe as God's body (1984:69) though not in a strictly analogous way to the human body. She develops her argument in favour of the corporeality of God by looking at three key facilities normally attributed to God - perception, action and omnipresence. She asks:

How does God think, or know, about the world and how can he act towards it, in the

creative, providential and self-communicative ways which lie at the heart of the Christian affirmation that God is love? (1984:77).

Insofar as God's action in the world is concerned, Jantzen argues that it can be better understood in embodied terms rather than by some kind of process akin to telekinesis (1984:87, 88). The embodied model of God emphasises the dependence of the universe on God, rather than the dualist model which suggests that the universe and its laws are independent of God, which comes close to Deism.

Jantzen's explanation of God's embodiment in relation to the traditional doctrines of

Though Jantzen's is one of the earliest modern considerations of this topic, it is interesting that Sallie McFague's treatment of the issue (Models of God: Theology for an Ecological Nuclear Age) has received so much more attention than Jantzen's. 
omniscience and omnipotence is somewhat more complicated. God is traditionally held to be aware of all that is happening in the universe. Using the human analogy of perception through the senses, Jantzen suggests that a "much less mystifying doctrine of divine perception can be offered" (1984:77) if it is posited that God is embodied as the universe, rather than suggesting that God is incorporeal and perceives what is happening through some disembodied process. Perception, for a disembodied God, requires something else mediating the affairs of the universe - a problematic notion she argues. Instead, she argues that God knows, or perceives in an analogous way to the way we perceive our own bodily awareness of hunger, joy or pain. This direct and unmediated perception leads us to consider the universe as the body of God.

Thirdly, the doctrine of God's omnipresence is usually used to deny the embodiment of God - having a body must locate one spatially and thus one cannot be everywhere. It might be possible to argue that God's body is huge and co-terminus with the universe. However, Jantzen does not want to argue this either. Omnipresence, she argues, is a religious concept (1984:97). In order to pursue this argument she distinguishes between omnipresence and permeation. God does not permeate the entire universe she suggests, but is present in all the universe. Starting with the understanding of human presence, she notes that we do not have to be bodily present in order to be seen as present. For example, if I were ill and confined to bed, but had a lecture I had prepared read to my students, I could in some senses be said to be present in the classroom. Likewise, Jantzen argues, God does not need to permeate all space, but rather to be aware of all parts of the universe and able to influence them (1984:96). "Omnipresence is a different concept from permeation, whether 'spiritual' or physical." (1984:96) This accords with the Christian understanding that God does not permeate all creation but is present in all creation. The example she uses is that God is said to be more present in a person than in a lamp post, and in the sacrament of the Eucharist than an act of terror; though of course in some senses God is present in them all. In other words we give religious significance to the idea of presence.

John Macquarrie, in his foreword to God's World, God's Body calls Jantzen's thesis 'startling' but also notes that her argument is 'sober' and 'restrained'. (MacQuarrie in Jantzen 1984: ix, x) If these ideas are startling, her consideration of the understanding of God fifteen years later in Becoming Divine might be viewed as positively astounding.

In Becoming Divine Jantzen sets out to write a feminist philosophy of religion. Using the insights of the psychoanalyst Jacques Lacan, she describes how the philosophers of religion in the Christian West have constructed a god who looks suspiciously like 'his' creators - an omnipotent patriarch who, removed from his creation, presides over it, who is rational, male and disembodied. Jantzen thus sets out to create a god according to her gender (Jantzen 1998:254). God is "a name to describe the possibilities of awareness and transcendence" and "the horizon for human becoming" (1998:12).

Her principal conversation partner in this book is the French philosopher Luce Irigaray who describes becoming divine as the task for humanity:

...to become divine men and women, to become perfectly, to refuse to allow parts of ourselves to shrivel and die that have the potential for growth and fulfilment (Irigaray quoted in Jantzen 1998:6).

The process of becoming divine and refusing to allow parts of ourselves to shrivel contrasts with the dominant Western Christian fascination with and dread of death - necrophilia and necrophobia (1998:129). So human beings are described as 'mortals' (rather than 'natals') and much of the focus of Christianity is on what happens after life, treating this life as merely a preparation for something better. She notes too the connections between death and gender: 
...since the efforts of mastery which manifest themselves in sexism are closely connected with the desire to master other (m)others, the need to conquer death is also imbricated in racism, colonialism, homophobia and other forms of dominance $(1998: 132)$.

She sets out to disrupt this dominant symbolism and to explore therefore how we might construct god if we were to use the imagery of 'natals' rather than mortals and 'flourishing' rather than death. She argues that birth is even more fundamental than death and if we were to take birth as the centre of our imaginary, then rather than being preoccupied with other worlds, or heaven, we would take our own world much more seriously and care for it. Centring birth and flourishing rather than death would enable women (and of course other oppressed groups) as well as men to become subjects (in the Lacanian sense) and the earth to bloom. ${ }^{6}$

In order to disrupt the dominant symbolic she sets out to replace the "traditional masculinist projection of God with a feminist pantheist projection" (1998:265). In other words she looks at how the story of God might be told, if told by women instead. She acknowledges that theologians usually fear pantheism as a threat to God's autonomy. However, she suggests that it is dualism rather than pantheism that is the problem. It is dualism that reduces God to 'otherness'. It is dualism that separates humanity from the rest of creation. And it is dualism that separates body from soul. It is also dualism that separates immanence and transcendence. But these are not opposites:

Just as beauty cannot be detached and float free from the physical matter of a painting or sculpture, nor can transcendence float free of its sensible configuration. But that does not dissolve transcendence into reductionism any more than aesthetics can be dissolved into physics (1998:272).

Borrowing therefore from Irigaray, Jantzen speaks of a 'sensible transcendental', to re-state her theme of God's World, God's Body, namely that God is a wholly immanent transcendent. However, this time around, Jantzen also makes use of the work of process theologians and emphasises the 'process' of the divine which she describes as the divine horizon:

Divinity in the face of the natals is a horizon of divine becoming, a process of divinity

ever new, just as natality is the possibility of new beginnings (1998:254).

This has implications for our understanding of humanity. I will explore some of these implications later.

\section{Sin, Salvation and Flourishing}

Jantzen's early doctrine of $\sin$ is a more or less standard understanding: $\sin$ is acquiescence in anything that falls short of God's glory. Salvation entails accepting God's grace in Jesus Christ which enables us to be freed from self-absorption (Jantzen 1984:7, 8). In God's World, God's Body, because of her concern to offer a holistic understanding of both God and humanity, she stresses that sin, and therefore salvation, involves not just the soul, but the whole human person, including the body, but she does not explore what this might entail.

However, by the time of Becoming Divine she is far more critical of the masculinist categories of theology and is aware of the feminist critique that exposes the definition of sin as that which is 'other' than the patriarchal way. She cites Valerie Saiving's work ${ }^{7}$ which

6 It is important to note that Jantzen does not set up natality and death as opposites. Both are present in the Christian tradition, but too little attention is paid to one and too much to the other.

7 Saiving, V, 1979. "The Human Situation: A Feminine View” in Christ, C and Plaskow, J (eds.) Womanspirit 
points out the gendered nature of theology's connection between sin and salvation. For example, the traditionally understood sins of pride and the will to power are different from the sins of women who are more likely to be guilty of lack of self-esteem. ${ }^{8}$

Jantzen does not stop however, at redefining a feminist concept of $\sin$. She takes a much more radical line and suggests that the Christian metaphor of salvation needs to be balanced with another metaphor, namely that of flourishing. She argues that although theologians know that salvation is a metaphor we do not treat it as such and instead convert it to a literal truth. She asks: "Why should the model of salvation have received so much more attention than any other model?" (1998:159). Simply put, salvation as a metaphor commends itself in a context where there are unequal power relationships, where the view of the human state is that we are in need of rescuing, where we hope to escape this world. Salvation also implies dependence and the need for rescue rather than implying the invitation to become creative and flourishing.

Salvation as a metaphor relies heavily on the idea that something happens after death. In other words, death becomes released from the problems of life and therefore death, rather than life becomes significant. However, "Flourishing is the unacknowledged foundation of salvation in the western theological text" (1998:157), though flourishing as a metaphor is hardly mentioned in theological texts except in the case of the theologies of liberation and exponents of the social gospel. It is significant that the theologies of liberation critique traditional theologies on precisely this point, viz. that focussing on eternal destiny distracts from engaging with the daily struggles of especially the poor. Focus on the hereafter can be a way of not challenging the unjust structures of today.

Conversely, the metaphor of flourishing focuses attention on "an inner dynamic of growth, with no need for interference from the outside" (1998:160), though of course flourishing draws on and supports external sources, as a plant draws water and nutrients from the soil. Flourishing emphasises the web of connectedness of life.

Working with this metaphor of flourishing, God is seen, "not as external to the world, but its source and well-spring" (1998:162) and Jesus is not the saviour sent from outside to rescue us, but "the one who manifests what it may mean to live fully and naturally in the creative justice of God." (1998:162) Again, this Christology is not unfamiliar to feminist and other liberation theologians' readings of Jesus.

\section{Free and Flourishing Natals: Jantzen's Anthropology}

As one might expect with Jantzen's insistence on the embodiment of God, human bodies too are very significant. If immanence and transcendence are inseparable in God, so too are they in humanity. There is no free floating soul. Much less is the spirit/ soul to be valued over the body. Consciousness develops out of and shapes our physical being. Our different embodied experiences naturally lead to our unique conscious and unconscious selves (Jantzen 1998:274).

Furthermore whilst Jesus is the embodiment of God, he cannot be the entire embodiment of God because he did not encompass all of humanity. He was Jewish and male

Rising: A Feminist Reader in Religion. San Francisco: Harper and Row, p. 39.

$8 \quad$ This idea has of course been followed by a number of women's theologies. See for example Hampson, D 1990. Theology and Feminism. Oxford: Blackwell; Engel, MP, 1990. "Evil, Sin and the Violation of the Vulnerable" in Thistlethwaite, S \& Engel, M (eds.): Constructing Christian Theologies from the Underside. San Francisco: Harper; and Acolaste, EA, 2001. "Re-thinking Sin and Grace: An African Evangelical Feminist Response to Niebuhr" in Njoroge, N \& Dube, M (eds.): Talitha Cum: Theologies of African Women. Pietermaritzburg: Cluster. 
(and one might add any other particularities one chose). Therefore all men and women are potentially the embodiment of the divine. Jesus' incarnation "leaves room for other incarnations" (Jantzen 1998:17). ${ }^{9}$ Becoming divine is the invitation for all humanity. By this Jantzen does not suggest we should 'play God' in lording it over others ("becoming divine is inseparable from solidarity with human suffering" (1998:263)) but rather that we should embody the divine in promoting our own and others' flourishing. This is especially important for women who, classically, have not been seen to image the divine and who must therefore bring god to life through a different symbolism (1998:275).

The promise of flourishing is a theme of both the Biblical prophets and the Wisdom literature (for example Zechariah 9:10-17; Hosea 14:3-7, Psalm 92:12 and Proverbs 14:4). In the New Testament writings although the specific vocabulary of flourishing is absent, there the idea is still manifest, for example in Ephesians 3:19-20, 2 Corinthians 9:8 and the Fourth gospel in particular. However, the focus has shifted instead to the metaphor of salvation. This over-emphasis on salvation becomes even stronger from the Reformation onwards. One of the consequences of this is that we value saviour figures, thus reducing the rest of us to helpless creatures in need of ruling and rescuing. This is precisely the basis for such structures as patriarchy, racism and colonialism.

The metaphor of flourishing instead suggests a mutual commitment and responsibility to one another's flourishing. We depend on others just as much as they depend on us. There is no room here for rescuers and dependents. Drawing on Levinas, Jantzen develops an 'ethics of natality' (Jantzen 1998: 231-248). Though she critiques his masculinist approach, she argues with him both against the reduction of the other to an ontological category, and for the recognition of the other as a face who calls forth justice. This "justice in the face of the natals" is the way in which the divine is called forth: "God can only be defined through human relations" (1998:250). The 'other' is not to be ruled, saved, or categorised in any way, but always to be responded to with sympathy and love, allowing her to make fresh and unexpected new beginnings in relationship. Natality is thus a constant coming into being of beings in relationship and it is in such relationship that the divine horizon emerges.

\section{Springs of Newness and Beauty}

Grace Jantzen's writing projects, especially her last works Becoming Divine and Foundations of Violence, cover a vast spectrum. As she herself acknowledges, her writings cross a number of academic disciplinary boundaries (Jantzen 2004:vii). To try and draw one or two conclusions from her work immediately exposes one to the risk of misrepresenting her. Furthermore, like many good theorists, different ideas seem to commend themselves at different times as I work on different themes, so I may only highlight my own present interests. However, with these caveats in mind I would like to suggest some reasons that I believe her writing deserves more attention, especially from theologians.

\section{Addressing the Ecological Crisis}

That theology today needs to address the ecological crisis goes without saying. Jantzen's model of the universe as the body of God invites a reverence and care for all creation, not because human beings have been given 'dominion' over creation, but because it is the very body of God and thus the place of encounter with the divine. Furthermore, because all of

Rita Nakasima Brock, 1988 develops this point in a similar way when she suggests that the entire Christian community is the incarnation of God. 
the universe is God's body, all parts of the body are related. This applies not only to human beings, but we recognise that we are also related to trees, elephants, rivers and birds as well.

\section{Challenging Dualisms}

Much has been written in recent years about the consequences of working in dualistic categories such as body/spirit or God/creation. Despite challenges to this way of thinking we still live with the notion that what has been defined as 'like God' (that is, disembodied, rational) is clearly better and more desirable than, for example, the body and the emotions and the material world. Particularly in Christian religious understanding since the Reformation there has been an exaltation of the rational, and an association of the body with that which is sinful, 'fallen' and female. Understanding the universe as the body of God collapses the basis for such dualistic thinking. Following the challenge to the body/soul dualism, Jantzen challenges the notion of salvation of the soul as the end of religious living. Instead, flourishing involves all the bodily requirements for living now health, food and the material necessities for living. This is good news especially for those whose material well-being and bodily needs have not formed the focus of theological attention.

\section{Challenging Structural Injustices}

Liberation theologians have pointed out the ways in which a focus on death and the hereafter has led theology to ignore questions of injustice in the here and now. A theology that promotes flourishing encourages us to recognise and name structures which deny flourishing and to look for ways to challenge such injustices. As Jantzen herself points out, flourishing is not a sentimental or romantic notion for we need to recognise who flourishes at whose expense (Jantzen 1998:165). The imagery of flourishing has sound Biblical roots, as does the prophetic challenge to injustice. Jantzen's re-examination of the prophetic tradition is a fine example of 'searching the scriptures" ${ }^{10}$ to bring good news to the poor.

\section{Christology}

Jantzen's critique of salvation as the only metaphor has been noted. Though she takes the point further than most theologians, she is not alone in pointing out the problems of Anselm's understanding of atonement as satisfaction. ${ }^{11}$ Rather than drawing on other understandings of salvation as do these writers, though, she instead suggests the metaphor of flourishing which presents Jesus as one most gloriously alive who shows us what it means to live compassionately, justly and wisely. This Christology does not deny death (Jesus' or ours). However it does draw attention away from an imbalanced focus on blood sacrifice for human sin, and instead offers models for living well. Again, this is particularly good news for those who have been told that suffering is simply to be endured and a natural consequence of our sinful state.

Challenging Individualism

Theology in Southern Africa takes place in the rich but challenging interface of post-

See Schüssler Fiorenza, 1993.

11 See for example James Cone, 1997. God of the Oppressed (revised edition). Maryknoll, NY: Orbis; Rosemary Radford Ruether, 1998. Women and Redemption. Minneapolis: Fortress Press; Carter Heyward, 1999. Saving Jesus From Those Who Are Right: Rethinking What it means to be Christian. Minneapolis: Fortress Press; Dolores S Williams, 1993. Sisters in the Wilderness: The Challenge of Womanist Godtalk. Maryknoll, NY: Orbis. 
modernism, enlightenment and traditional African culture. Although Jantzen's philosophical roots are clearly in the Western tradition and deeply influenced by the post-structuralists, her collaborative style of working and her focus on communal flourishing locate her values very much in the traditions of Africa. This makes her a helpful companion in doing theology in this part of the world. ${ }^{12}$ For example, she reminds us that flourishing is not an individualistic goal. We need always to examine at whose expense we flourish. Flourishing is not just 'my' goal but 'ours'.

\section{Methodology}

Jantzen's enquiry into who tells the story is an important reminder that we can all too easily fall prey to a limited and limiting metaphor. Her reminder to listen for new stories, especially from those whose stories have not been heard before, is an important one in the project of liberation theology.

\section{Springs of Beauty}

For those of us who have struggled through many 'uncharming' texts, one of the great joys of reading Jantzen's work is her elegant prose, often with hints of humour. Furthermore, her background in philosophy and rigorous self-examination make her writings some of the most satisfying of contemporary feminist theology. These attributes should not be undermined. Good theology is a work of beauty and she has much to teach us. Indeed her work seeks to recover beauty as a way to inspire resistance to the death and violence of our habitus.

Preoccupation with death requires a refusal of beauty, or its displacement into some less threatening sphere. Conversely, response to beauty reconfigures consciousness towards creativity and new life. Beauty, creativity, seeks to bring newness into the world, a newness that is at odds with violence (Jantzen 2004:viii).

\section{Conclusion}

Jantzen's life story was cut short by her early death. Her death also precluded the conversation she hoped for with others. In the Preface to Foundations of Violence she noted that the 'long story' she sought to tell 'at a time when grand narratives are suspect' (Jantzen 2004:vii) would require the intervention and comment of her readers. She recognised that the story of God is one in which we all need to participate in order for there to be healing and hope for those whose voices have not been listened to in constructing the story thus far. The reminder is a timely one for those who seek to speak of (and for) God.

12 I am indebted to Jonathan May for this insight. 


\section{BIBLIOGRAPHY}

Acolaste, EA 2001. "Re-thinking Sin and Grace: An African Evangelical Feminist.

Response to Niebuhr" in Njoroge, N \& Dube, M Talitha Cum: Theologies of African

Women. Pietermaritzburg: Cluster.

Brock, R 1988. Journeys by Heart: A Christology of Erotic Power. New York: Crossroad

Engel, MP 1990. "Evil, Sin and the Violation of the Vulnerable" in Thistlethwaite, S and

Engel M. (eds.) Constructing Christian Theologies from the Underside. San

Francisco: Harper.

Hampson, D 1990. Theology and Feminism. Oxford: Blackwell.

Jantzen, G 1984. God's World, God's Body. Philadelphia: The Westminster Press.

Jantzen, G 1987. Julian of Norwich: Mystic and Theologian. London: SPCK.

Jantzen, G 1995. Power, Gender and Christian Mysticism. Cambridge: Cambridge University Press.

Jantzen, G 1998. Becoming Divine: Towards a Feminist Philosophy of Religion. Manchester: Manchester University Press.

Jantzen, G 2004. Foundations of Violence. London: Routledge.

McFague, S 1987. Models of God: Theology for an Ecological, Nuclear Age. Philadelphia: Fortress Press.

Schüssler-Fiorenza, E (ed.) 1993. Searching the Scriptures. London: SCM. 